\title{
Role of Cystoseira mediterranea extracts (Sauv.) in the Alleviation of salt stress adverse effect and enhancement of some Hordeum vulgare L. (barley) growth parameters
}

\author{
Leila Bensidhoum ${ }^{1} \cdot$ El-hafid Nabti $^{1}$ (1)
}

Received: 6 August 2020 / Accepted: 21 December 2020 / Published online: 12 January 2021

(c) The Author(s) $2021 \quad$ OPEN

\begin{abstract}
Cystoseira mediterranea (Sauv.) extract was tested for its ability to restore barley (Hordeum vulgare) growth under salt stress $(350 \mathrm{mM} \mathrm{NaCl})$, shoot growth; membrane integrity; lipid peroxidation and hydrogen peroxide determination were performed. In normal conditions, the obtained data revealed the ability of the extract to stimulate most of barley growth parameters. However, it showed significant effect on most of barley growth parameters (plant height, fresh and dry weight of shoots and roots) and chlorophyll content, under salt stress. The measurement of stress parameters (membrane integrity, lipid peroxidation and hydrogen peroxide) revealed significant effect of $C$. mediterranea extract on reducing the deleterious impact of salt stress on barley seedlings.
\end{abstract}

Keywords Cystoseira mediterranea $\cdot$ Salt stress $\cdot$ Barley $\cdot$ Membrane integrity $\cdot$ Lipid peroxidation $\cdot$ Hydrogen peroxide

\section{Introduction}

The human population is expected to reach 9.7 billion by the end of 2050 and could peak at nearly 11 billion around 2100 [1]. Such growth inevitably will require more food to ensure food security. Thereby, a significant increase in agricultural land devoted to food production seems inevitable [2]. Salinity is one of the major factors affecting plant growth and development, consequently reduces crop yields and production. Desertification and high rate of evaporation in arid and semi-arid regions apply great pressure to the irrigated agriculture, owing to rapid rate of salinization of soil and water causing, arable land productive agricultural potential, reduction. Irrigation used in arid and semi-arid areas insures the development of agriculture and meets nutritional needs [3]; however, the poor quality of available water often affects soil and crops. The risk of the land loss by salinization has increased sharply in recent years, as a result of the intensified irrigation.
Additionally, the presence of soluble salts in irrigation water and evaporating power of the air in arid and semiarid zones frequently leads to secondary salinization of soils in irrigated areas [4].

Salinity and population growth are increasing rapidly and simultaneously at the same rate, which further exacerbates food insecurity [5]. In fact, the pressure resulting from the combination of these two natural and human factors inexorably decreases agricultural lands availability and consequently reduces global food.

In recent years, several biological inputs have been developed and commercialized in order to alleviate the drastic effects of biotic and abiotic stress and to improve plant growth and health. Likewise, these products improve soil structure and quality, they named stimulating products or bio-stimulants habitually provide innovative solutions for soil fertilization and crop protection [6], and these biological molecules are mainly macroalgae and their derivative products.

Leila Bensidhoum, nabtielhafid1977@yahoo.com | 'Laboratoire de Maitrise Des Energies Renouvelables, Faculté Des Sciences de La Nature Et de La Vie, Université de Bejaia, Bejaia 06000, Algeria. 
Marine algae and their derivative products are of great scientific and agronomic interest, since they have an important role in soil quality and plant development enhancement. The crude extracts of algae includes several compounds involved in several mechanisms of plant growth. Which may explain the biostimulant effects. Numerous studies have revealed the benefits effects of algal extracts on plants such as improvement of crop performance, yield and plant resistance to biotic and abiotic stress [7, 8]. Algal extracts could also improve nutrient availability and productivity. In stressed environment, alga and their products constitute the major source for compatible solutes like betaines, amino acids and 3-dimethylsulfoniopropionate (DMSP) [9]. Cystoseira mediterranea is a brown marine algae (Fucales, Phaeophyceae), endemic species of the Mediterranean Sea growing on littoral rocky shores of the Northwestern Coast [10].

The Algerian coast has an unusually rich diversity of seaweeds; however, there are only few studies on their biostimulant properties. The current investigation mainly focuses on the determination of $C$. mediterranea extract capability to restore barley growth under salt stress.

\section{Material and methods}

\subsection{Seaweeds collection}

Seaweed C. mediterranea (Sauv.) used in this experiment was collected from the coastal area of Bejaia-Algeria (Boulimat 36 $48^{\prime} 42.1^{\prime \prime} \mathrm{N} 4^{\circ} 58^{\prime} 53.9^{\prime \prime} \mathrm{E}$ ). The collected seaweed samples were handpicked washed thoroughly with a seawater to remove all the impurities. Samples were then brought to the laboratory and washed with tap water to remove epiphytes and adhering sand particles. Samples were air-dried and powdered using electric blender then stored in smoked glass jars.

\subsection{Seaweed extract preparation}

Algal powder $(10 \mathrm{~g})$ was homogenized in $100 \mathrm{ml}$ of distilled water. The solution was autoclaved for $20 \mathrm{~min} / 120^{\circ} \mathrm{C} / 15 \mathrm{psi}$ to release the constituents. The supernatant was finally, transferred in sterile flasks. Different concentrations of 100 , $50 \%$ and $20 \%$ were prepared by extract dilution in distilled water, then stored at $4{ }^{\circ} \mathrm{C}$ for further applications.

\subsection{Surface sterilization of barley seeds}

Barley seeds (Hordeum vulgare L.) were surface-sterilized as described by Götz et al. [11]. First, seeds are treated with $70 \%$ ethanol for $1 \mathrm{~min}$, and then with $12 \%$ acidified hypochlorite for $15 \mathrm{~min}$. Sterilized seeds were finally, washed thoroughly in sterile water.

\subsection{Halotolerance of baley seeds}

Before proceeding to this experiment, the halotolerance of barley seeds was studied in order to determine which $\mathrm{NaCl}$ concentration should be used.

Seeds imbibed in tap water for $1 \mathrm{~h}$ at room temperature were placed in Petri dishes layered with sterile filter paper and soaked with $6 \mathrm{~mL}$ per Petri dish of water (control) or various $\mathrm{NaCl}$ solutions $(50 \mathrm{mM} ; 100 \mathrm{mM} ; 150 \mathrm{mM}$; $200 \mathrm{mM} ; 250 \mathrm{mM} ; 300 \mathrm{mM} ; 350 \mathrm{mM}$ and $400 \mathrm{mM}$ ). All tests were repeated in triplicate (13 seeds per Petri dish) [12]. The experiment was conducted in darkness at room temperature $25^{\circ} \mathrm{C}$. Germination counts were made every day during 15 days, and the final germination percentage was determined at the end of the experiment.

\subsection{Barley germination under salt stress}

The halotolerance test showed that $350 \mathrm{mM}$ of $\mathrm{NaCl}$ is stressful. The protocol was similar to the experimental protocol in Sect. 2.4. In this test, filter paper was soaked with tap water (Control), salt solution $350 \mathrm{Mm} \mathrm{NaCl}$, Cystoseira extracts (20\% and 50\%) and the solution test (Cystoseira extracts + salt solution). Seeds germination carried out for 15 days by counting the germinated seeds in each box every day. At the end of the experiment, the percentage of germination in each box was determined. All tests were repeated in triplicate (13 seeds per Petri dish).

\subsection{Barley growth under salt stress}

After $1 \mathrm{~h}$ in tap water, barley seeds were sown in soil. The experiment consists of nine pots ( 3 seeds per pot at a depth of $1 \mathrm{~cm})$. Six experiments were prepared: Experiment 1: Control, seeds were watered with tap water $(5 \mathrm{ml} /$ pot); Experiment 2 and 3: Seeds were watered with Cystoseira extract $20 \%$ and $50 \%$, respectively. Experiment 4, 5 and 6: Seeds were sown in saline soil and watered with tap water, cys. extract $20 \%$ and cys. extract $50 \%$, respectively. All experiments were conducted under natural conditions at temperature $23-28{ }^{\circ} \mathrm{C} / 15$ days. Growth parameters: plant height, fresh weight, dry weight of shoots and roots as well as chlorophyll a, b and total, were measured.

\subsection{Chlorophyll contents}

The photosynthetic pigment content was determined as described by Hiscox and Tsraelstam [13]. Barley fresh matter (100 mg) was cut and mixed in test tube containing $7 \mathrm{ml}$ of Dimethyl sulfoxide. The mixture was incubated at 
$65^{\circ} \mathrm{C}$ for $30 \mathrm{~min}$. After incubation, the sample was transferred into a $25 \mathrm{ml}$ graduated cylinder and the volume was adjusted to $10 \mathrm{ml}$ with DMSO. The absorbance was measured immediately at 645 and $663 \mathrm{~nm}$. Chlorophyll a, $\mathrm{b}$ and total were determined according to the equations established by Arnon [14].

Chla $\left(\mathrm{g} \mathrm{I}^{-1}\right)=0.0127 \times A 663-0.00269 \times A 645$;

$C h l b\left(\mathrm{~g} \mathrm{I}^{-1}\right)=0.0229 \times A 645-0.00468 \times A 663$;

Total Chlb $\left(\mathrm{g} \mathrm{I}^{-1}\right)=0.0202 \times A 645-0.00802 \times A 663$;

where Chla is the chlorophyll a content; Chlb is the chlorophyll b content; Total $C h l$ is the total chlorophyll; $A$ is the absorbance.

\subsection{Measurement of stress parameters}

\subsubsection{Membrane integrity}

The study was performed following Radoglou et al. [15] modified $[16,17]$. Barley leaves $(20 \mathrm{~g})$ were washed with distilled water, then cut into small pieces and taken in test tubes containing $20 \mathrm{ml}$ of distilled water and incubated at $25^{\circ} \mathrm{C}$ for $2 \mathrm{~h}$. Electrical conductivity (C1) of the solution was measured using an electrical conductivity meter. Samples were autoclaved at $120^{\circ} \mathrm{C} / 20 \mathrm{~min}$ and then cooled at room temperature. The second conductivity (C2) measurement was obtained after stabilization at $25^{\circ} \mathrm{C}$. So, a maximum electrolytes leakage amount was determined by the following formula:

Membrane integrity $(\%)=(\mathrm{C} 1 / \mathrm{C} 2) \times 100$

where $\mathrm{C} 1$ is the electrical conductivity of the solution before autoclaving, $\mathrm{C} 2$ is the electrical conductivity of the solution after autoclaving.

\subsubsection{Estimation of lipid peroxidation}

Lipid peroxidation was determined by malondialdehyde (MDA) content evaluation, which is a product of oxidative degradation of lipids and unsaturated fatty acids. MDA content is determined according to Heath and Packer [18].

Plant materials $(50 \mathrm{mg})$ were grinded and diluted in $4 \mathrm{ml}$ of $20 \%$ trichloroacetic acid (TCA). This procedure was used to reveal free radicals present in the sample. The level of MDA serves as an index of lipid peroxidation, and the result was therefore, expressed in mg of MDA. The extract $(1 \mathrm{ml})$ was centrifuged at $10,000 \mathrm{rpm}$ for $10 \mathrm{~min}$ at $4{ }^{\circ} \mathrm{C}$. Supernatant $(0.5 \mathrm{ml})$ was added to $2 \mathrm{ml}$ of $0.5 \%$ thiobarbituric acid (TBA). The mixture was finally, heated at $95^{\circ} \mathrm{C}$ for $30 \mathrm{~min}$. After cooling, the mixture was centrifuged at $10,000 \mathrm{~g} / 10 \mathrm{~min}$ and the absorbance of the supernatant was measured at $532 \mathrm{~nm}$. The MDA content was calculated by the Beer-Lambert law: $\mathrm{OD}=\varepsilon . \mathrm{Cl}$, using the molar extinction coefficient of MDA $\left(\varepsilon=155 \mathrm{Mmol}^{-1} \mathrm{~cm}^{-1}\right)$.

\subsubsection{Determination of $\mathrm{H}_{2} \mathrm{O}_{2}$ content}

The experiment was performed according to method of Sergiev et al. [19] modified. Leaf tissues $(50 \mathrm{mg}$ instead $500 \mathrm{mg}$ ) were homogenized in ice bath with $2.5 \mathrm{ml}$ (instead $5 \mathrm{ml}$ ) $0.1 \%(\mathrm{w} / \mathrm{v}$ ) Trichloroacetic acid. The homogenate $(1 \mathrm{ml})$ was centrifuged at $12,000 \times \mathrm{rpm}$ for $15 \mathrm{~min}$, and $0.5 \mathrm{ml}$ of the supernatant was added to $0.5 \mathrm{ml} 10 \mathrm{mM}$ potassium phosphate buffer $(\mathrm{pH} \mathrm{7.0)}$ and $1 \mathrm{ml} 1 \mathrm{M} \mathrm{KI}$. The OD of supernatant was recorded at $390 \mathrm{~nm}$. $\mathrm{H}_{2} \mathrm{O}_{2}$ content was determined using the extinction coefficient $0.28 \mu \mathrm{M}^{-1} \mathrm{~cm}^{-1}$.

\subsection{Statistics}

Statistical analyzes were performed by analysis of variance (One Way ANOVA) using the GraphPad PRISM software. Differences between treatments were separated by the least significant difference test at a 0.05 probability level.

\section{Results and discussion}

\subsection{Seeds germination and barley growth}

The results show that $\mathrm{NaCl}$ has significantly affected seed germination. The algae extracts (Cys 20\% and 50\%), promoted barley seeds germination under stress conditions, and the germination kinetics is similar to the control. These results showed clearly the deleterious effect of salt stress as well as the remarkable ability of Cystoseira extract to restore seeds germination affected by salt (Fig. 1).

Plant growth parameters measurement displayed that both algal extract concentrations (20\% and 50\%) stimulated the most of parameters plant height $(15.87 \pm 1.12 \mathrm{~cm} ; 14.37 \pm 0.62 \mathrm{~cm})$, root length $(39.83 \pm 1.77 \mathrm{~cm} ; 40.66 \pm 0.88 \mathrm{~cm})$, shoots fresh weight of $(1.49 \pm 0.11 \mathrm{~g} ; 1.42 \pm 0.06 \mathrm{~g})$, roots fresh weight of $(1.45 \pm 0.08 \mathrm{~g} ; 1.73 \pm 0.18 \mathrm{~g})$ as well as the dry weight of shoots $(0.37 \pm 0.03 \mathrm{~g} ; 0.31 \pm 0.05 \mathrm{~g})$ and roots $(0.28 \pm 0.02 \mathrm{~g} ; 0.29 \pm 0.02 \mathrm{~g})$, compared to the untreated control $(13.62 \pm 0.62 \mathrm{~cm} ; 31.33 \pm 1.11 \mathrm{~cm} ; 1.04 \pm 0.08 \mathrm{~g}$ and $1.25 \pm 0.06 \mathrm{~g} ; 0.26 \pm 0.03 \mathrm{~g} ; 0.28 \pm 0.01 \mathrm{~g}$, respectively) (Figs. 2, 3).

Salt stress affected significantly all barley growth parameters. The addition of algal extract (20\% and $50 \%)$ in the soil restored significantly all growth parameters. According 
Fig. 1 Effect of Cystoseira mediterranea extracts on barley seeds germination percentage under normal and salt stress conditions

Fig. 2 Effect of Cystoseira mediterranea extract on barley growth under normal and salt stress conditions. a Shoot length; $\mathbf{b}$ root length; c fresh weight of shoots; $\mathbf{d}$ fresh weight of roots; e dry weight of shoots; $\mathbf{f}$ dry weight roots; $350 \mathrm{mM}$ : $350 \mathrm{mM} \mathrm{NaCl}$; cys: Cystoseira mediterranea; ns: Not significant $(p \geq 0.05)$; ${ }^{*}$ significant $p \leq 0.05 ;{ }^{* *}$ significant $p \leq 0.01 ;{ }^{* * *}$ :significant $p \leq 0.005 ;{ }^{* * * *}$ significant; $p \leq 0.001$
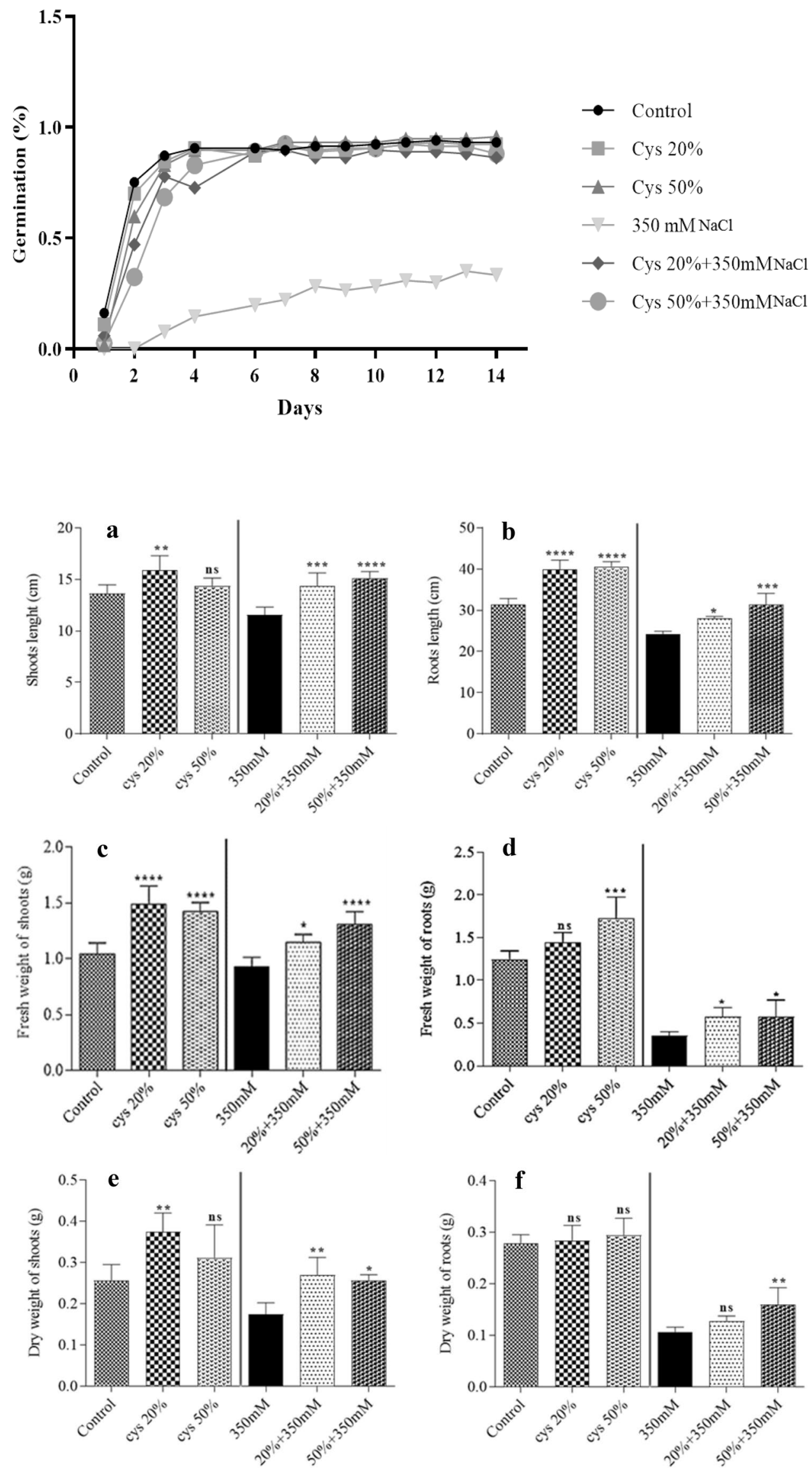
Fig. 3 Effect of Cystoseira mediterranea extracts on barley growth under saline and non-saline conditions

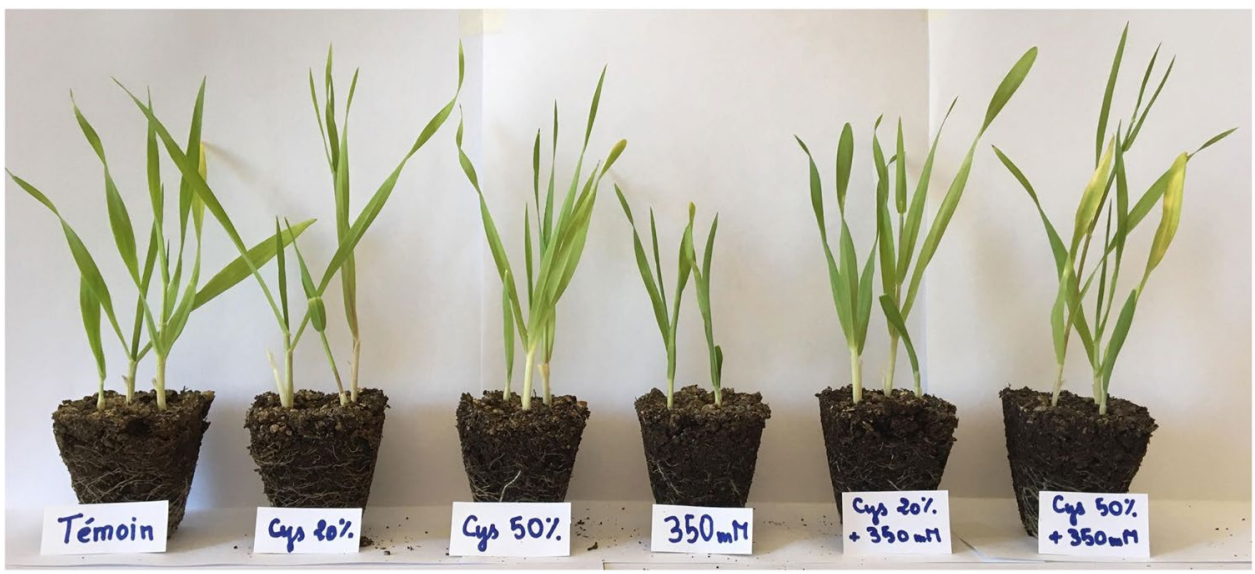

to Sharif et al. [20], the degree of sensitivity to salt stress depends on vegetative stage during stress exerted. For example, cotton is more sensitive at the seedling stage than at the maturity [21]. To evaluate salt tolerance at the germination stage, several germination indicators could be used [22]. Singh et al. [23] found that the tomato seeds germination rate decreased with salt stress increasing. They also demonstrated that the dry weight ratio (roots/ shoots) of seedlings and the $\mathrm{Na}+$ content increase, while the $\mathrm{K}+$ concentration decreases.

Seaweeds constitute an important source of nutrients for the seeds and retain water in its external environment, which reduces the rate of dehydration [24]. Seaweed extracts have the ability to increase the concentration of antioxidants in stressed plants [25]. Zhu et al. [26] mentioned that salinity negatively affects the length of the coleoptile and the development of plant roots. Amira et al. [27] reported that seaweed extracts could completely decrease the aggressive effect of low concentration of salt stress and partially the effect of high concentration of stress. Sivasankari et al. [28] discovered that Caulerpa chemnitzia and Sargassum wightii extracts increase the percentage of vine seeds germination. The germination rate is proportional to the concentration of the extract between 5 and $20 \%(\mathrm{v} / \mathrm{v})$ and then decreases for the concentrations between 20 and $50 \%$. Above a $50 \%$ algal extract concentration, germination is inhibited. Kumar and Sahoo [29] reported that the $20 \%$ dilution of Sargassum wightii extract significantly stimulated germination of Triticum aestivum seeds.

The ability of studied extracts to restore germination and growth of barley may be explained by the fact that seaweed extracts are rich in osmoprotective compounds, particularly free amino acid molecules. According to Ghoul et al. [9], the restoration of wheat plant growth under salt stress is due to the compatible solutes contained in the algae (various betaines, proline, amino acids and dimethylsulfoniopropionate). These compounds reduce the effect of stress on plants and provide nitrogen and energy for the plant. Compared to plants stressed, the treatments with algae extracts allow a better production of biomass of plants cultivated under saline conditions. However, it should be noted that the biomass of plants stressed and treated with algae extracts always remains significantly lower than those of unstressed plants. These results suggest that the presence of the extracts, although beneficial, does not provide total protection against salt stress [30].

\subsection{Chlorophyll contents}

Salinity stress causes a perturbation in photosynthesis and therefore reduces plant growth and production. In this study, the chlorophyll content quantification carried out in order to verify the ability of $C$. mediterranea extract to alleviate salt stress impact. Results of this study showed that salt stress significantly reduced the chlorophyll content. Both concentrations of $C$. mediterranea under saline stress (Cys 20\%+350 mM NaCl and Cys 50\%+350 mM $\mathrm{NaCl}$ ) improve the content of barley seedlings in chlorophyll $\mathrm{a}$, and total compared to the control untreated (350 mM NaCl). In the absence of stress, C. mediterranea extract slightly improved chlorophyll content (Fig. 4).

It has been stated by Shaheen et al. [31] that salinity stress causes perturbation in gaseous exchange in plant processes like photosynthesis, substomatal $\mathrm{CO}_{2}$ concentration, and net $\mathrm{CO}_{2}$ assimilation and transpiration rate. Under salt stress, as a response to osmotic stress, plant reduce leaf area and chlorophyll content, defoliation, and carbon assimilation [32]. Salinity reduces the chlorophyll content, and this reduction is dependent on the intensity of stress and the degree of plant tolerance [33]. This reduction in chlorophyll contents could be related to the suppression of the enzymes responsible for chlorophyll synthesis [34]. Zhang et al. [35] reported that the increase in salinity levels reduces the chlorophyll $a$ and $b$ contents in cotton. 
Fig. 4 Chlorophyll content of barley grown under salt stress in the presence of different concentrations of Cystoseira mediterranea extract. cys: Cystoseira mediterranea; ns: Not significant $(p \geq 0.05) ;{ }^{* *}$ :significant $p \leq 0.01 ;{ }^{* * *}$ : significant $p \leq 0.005$

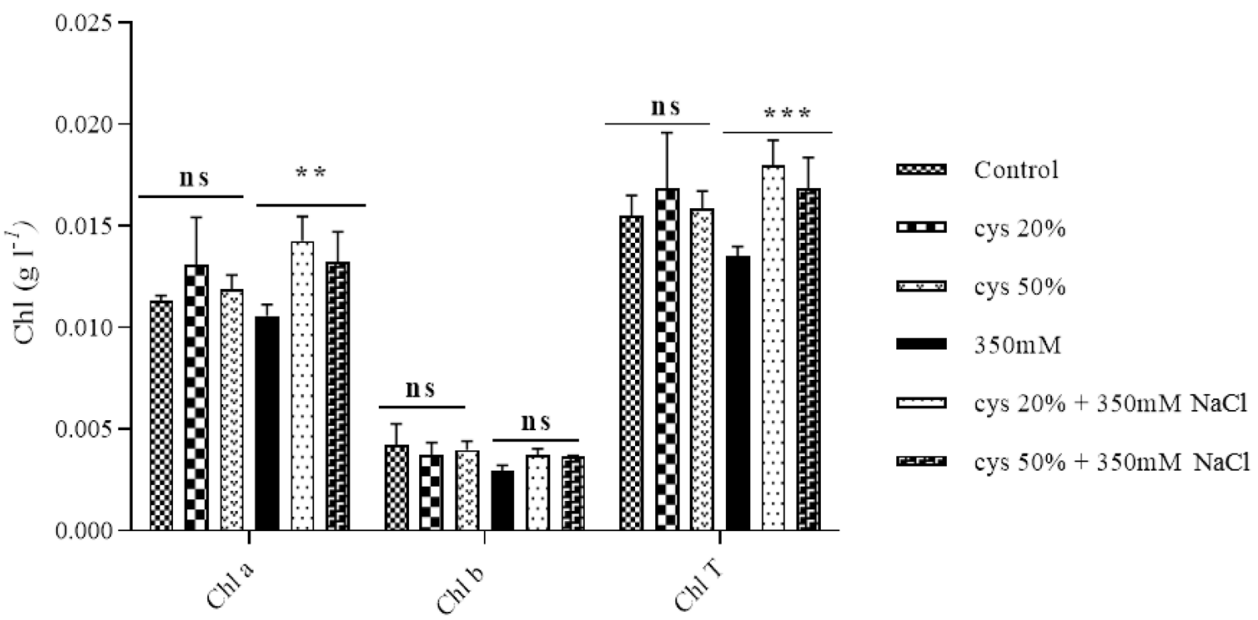

In this investigation, C. mediterranea increased the amount of chlorophyll content of barley under salt stress. Results obtained with stressed barley plants treated with $C$. mediterranea extracts revealed a higher chlorophyll contents than unstressed barley plants. Bozorgi [36] and Ramarajan et al. [37] showed that the application of algae to the bean plant as a foliar spray or incorporated into the growing medium increases the pigmentation of the leaves and shoots (especially Chl a). Likewise, the application of seaweed extract to eggplant significantly increases the chlorophyll content in two levels of salt stress $(54.76 \mathrm{Mm}$ and $82.14 \mathrm{mM}$ ). However, stressed plants show significantly higher chlorophyll contents than unstressed plants.

\subsection{Stress parameters}

\subsubsection{Membrane integrity}

The electrolyte leakage was estimated by measuring the electrical conductivity of the external medium. The obtained data showed that the extract Cyst 20\% and Cyst $50 \%$ reduced the leakage of electrolytes and therefore protected the membrane integrity of barley seedlings. Compared to the control, both concentrations of $C$. mediterranea extract displayed almost the same results; this means that these extracts can reduced the negative effect of $\mathrm{NaCl}$ (Fig. 4).

\subsubsection{Lipid peroxidation}

MDA was evaluated to determine the ability of $C$. mediterranea extract lipid peroxidation decrease in barley cell membranes. Salt stress caused a significant increase in MDA content in plants. A significant reduction $(p<0.05)$ of MDA was obtained with plants treated by cys $20 \%$ seaweed extract, whereas the cys $50 \%+$ extract reduced it slightly (Fig. 5).
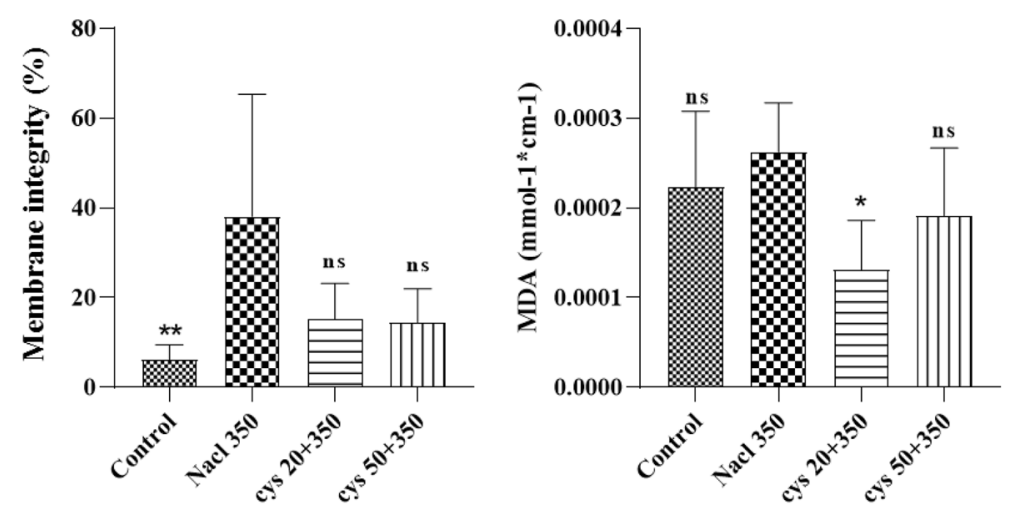

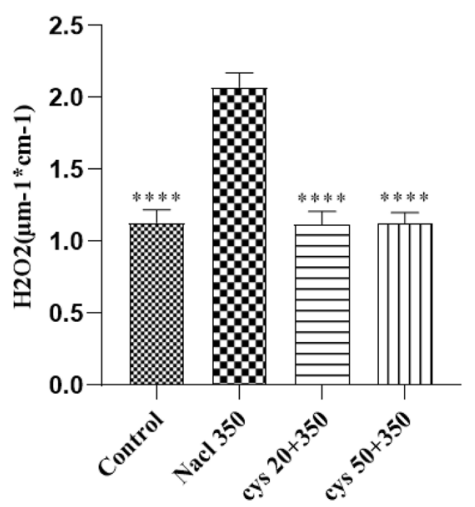

of $\mathrm{H}_{2} \mathrm{O}_{2} ; \mathrm{c} \mathrm{H}_{2} \mathrm{O}_{2}$ content; cys: Cystoseira mediterranea; ns: Not significant $(p \geq 0,05) ;{ }^{*}$ significant $p \leq 0.05 ;{ }^{* *}$ significant $p \leq 0.01 ;{ }^{* * *}$ significant $p \leq 0.005 ;{ }^{* * * *}$ significant $p \leq 0.001$
Fig. 5 Effect of Cystoseira mediterranea extract on the membrane integrity of barley seedlings in the presence and absence of salt stress. a Membrane integrity; b Lipid peroxidation; Determination

\section{SN Applied Sciences}




\subsubsection{Determination of $\mathrm{H}_{2} \mathrm{O}_{2}$ content}

Salt stress increased markedly the level of hydrogen peroxide $\left(2.07 \mu \mathrm{m}^{-1} \mathrm{~cm}^{-1}\right)$ compared to the control $\left(1.18 \mu \mathrm{m}^{-1} \mathrm{~cm}^{-1}\right)$. In comparison with the stressed control, the treatment with Cys $20 \%$ and $50 \%$ extracts reduced significantly $\mathrm{H}_{2} \mathrm{O}_{2}$ level of $(p<0.0001)$ (Fig. 5).

Reactive oxygen species generated by salt stress causes considerable damage to lipids and proteins and other biomolecules. This damage can lead to plants death [38]. The activation of the plant antioxidant system can adjust the disruption of cellular redox state [39, 40]. Recently, many reports have announced the ability of algae to activate cellular antioxidant machinery in plants under stress [41-43]. The evaluation of these three parameters (hydrogen peroxide, membrane integrity and lipid peroxidation) showed clearly the ability of $C$. mediterranea extract to mitigate the deleterious effect of salinity on barley seedlings.

Evaluating the level of hydrogen peroxide is a main step in stressed plants, as it is the important generator of reactive oxygen compounds, which cause oxidative stress. Several studies have confirmed the involvement of abiotic stresses in reactive oxygen species generation. Mezghani et al. [41] reported that Ulva rigida extracts possess strong radical scavenging activity; they suggest that the richness of these extracts in bioactive molecules will provide alga with strong protection for plant cells against oxidative stress. Sadasivam et al. [42] showed that the level of the accumulated hydrogen peroxide in tomato plants as well as the amount of brown spots on leaves increased considerably under salt stress. They suggested that these effects are due to the 3,3' diaminobenzidine (DAB) with peroxidases reaction. Recently, several algae compounds, including polyphenols, polysaccharides, and proteins, have been classified as potent antioxidants that protect cells against free radicals and reduce the progression of many chronic diseases [43].

Lipid peroxidation is a biochemical indicator of alterations induced by reactive oxygen species [44]; it takes place through the oxidation of unsaturated fatty acids, thus causing cell membrane and electrolytes leakage alteration [45]. The determination of the impact of salt stress on plants carried out by measuring the MDA amount and the lipid peroxidation intensity [46]. Lipid peroxidation expressed by MDA concentration is closely related to the disruption of the antioxidant machinery of stressed plants [47]; in our study, the treatment with C. mediterranea extract decreased significantly the MDA level that allows us to suppose that the cellular antioxidant machinery in barley was activated and the production of antioxidative enzymes increased by our seaweed extract.

The varied and rich composition of algae and their products are the source of its protective potential of plants in normal and stressed environments. Besides, they are the major source for compatible solutes for plant and bacteria in stressful environment [48]. Algae, by their composition in compatible solutes, restore plant growth in a stressful environment and enhance the potential of beneficial soil bacteria such as plant growth promoting rhizobacteria (PGPR). Ulva lactuca extracts enhanced Azospirillum brasilenses ability to restore wheat growth under salt stress [49] and restored the germination, protein and chlorophyll contents of wheat inoculated by P. fluorescens [50].

\section{Conclusion}

Cystoseira mediterranea (Sauv.) extract showed a protective mechanism for barley under saline conditions. In normal conditions, C. mediterranea extract stimulated most of barley parameters. Under salt stress, both concentrations ( $20 \%$ and $50 \%$ ) showed a significant effect, on chlorophyll content. This extract reduced significantly the deleterious effect of salt stress on barley seedlings. The results of this investigation encourage the transition towards a healthy culture "Bio-agriculture" beneficial to human health and the worldwide economy. Algal extracts utilization as biostimulants is emerging as a promising alternative to chemicals (fertilizers and pesticides) that are both harmful to the environment and to public health, and as a promising protective mechanism of stressed plants.

Acknowledgement The authors of this chapter are grateful to $\mathrm{Mr}$. Abbaci Hocine Teacher-Researcher at the University of Bejaia, FSNV, Laboratory of Mastery of Renewable Energies, for his help and collaboration.

Author contributions The first author carried out all the experimentation and wrote the article. The second author revised and corrected the manuscript.

\section{Compliance with ethical standards}

Conflict of interest The authors declare that they have no competing interests.

Open Access This article is licensed under a Creative Commons Attribution 4.0 International License, which permits use, sharing, adaptation, distribution and reproduction in any medium or format, as long as you give appropriate credit to the original author(s) and the source, provide a link to the Creative Commons licence, and indicate if changes were made. The images or other third party material in this article are included in the article's Creative Commons licence, unless indicated otherwise in a credit line to the material. If material is not included in the article's Creative Commons licence and your intended use is not permitted by statutory regulation or exceeds the permitted use, you will need to obtain permission directly from the copyright holder. To view a copy of this licence, visit http://creativecommons. org/licenses/by/4.0/. 


\section{References}

1. United Nations, Department of Economic and Social Affairs, World Population Prospects 2019. https://www.un.org/devel opment/desa/en/news/population/world-population-prosp ects-2019.

2. Steichen $P$ (2013) Terres, sols and sécurité alimentaire. Revue juridique de l'environnement, Lavoisier 38:595-612. ISBN 9782756205076.

3. FAO (2006) The Demand for the products of irrigated agriculture in Sub-Saharan Africa. FAO Water Report 31, Rome.

4. Marlet S, Vincent B, Vidal A, Bouarfa S, Wu J, Yang J, Zimmer D (2005) Gestion de l'eau et de la salinité et redistribution des sels dans les périmètres irrigués. Use of Water and Land for Food and Environmental Sustainability : 19th Congress on Irrigation and Drainage, September 10-18, 2005. Beijing, China. Revue, pp 12-18p

5. Farooq S (2009) Triticeae: the ultimate source of abiotic stress tolerance improvement in wheat. In: Salinity and water stress. Springer, Dordrecht, pp 65-71

6. Faessel L, Gomy C, Nassr N, Tostivint C, Hipper C, Dechanteloup A (2014) Produits de stimulation en agriculture visantà améliorer les fonctionnalités biologiques des sols et des plantes-Étude des connaissances disponibles andrecommandations stratégiques. BIO\&RITTMO. $156 \mathrm{pp}$.

7. Eyras MC, Defosse GE, Dellatorre F (2008) Seaweed compost as an amendment for horticultural soils in Patagonia. Argentina Compos Sci Util 16:119-124

8. Norrie J, Keathley JP (2006) Benefits of Ascophyllum nodosum marine-plant extract applications to "Thompson seedless' grape production. Acta Hortic 727:243-247.

9. Ghoul M, Minand J, Bernard T, Dupray E, Cornier M (1995) Marine macroalgae as a source for osmoprotection for Escherichia coli. Microb Ecol 30:171-181

10. Delgado O, Ballesteros E, Vidal M (1994) Seasonal variation in tissue nitrogen and phosphorus of Cystoseira mediterranea Sauvageau (Fucales, Phaeophyceae) in the Northwestern Mediterranean Sea. Bot Mar 37:1-9

11. Götz MCM, Gomes N, Dratwinski A, Costa R, Berg G, Peixoto R, Mendoça-Hagler LM, Smalla K (2006) Survival of gfp-tagged antagonistic bacteria in the rhizosphere of tomato plants and their effects on the indigenous bacterial community. FEMS Microbiol Ecol 56:207-218

12. Ramadoss D, Lakkineni VK, Bose P, Ali S, Annapurna K (2013) Mitigation of salt stress in wheat seedlings by halotolerant bacteria isolated from saline habitats. Springer Plus. https:// doi.org/10.1186/2193-1801-2-6

13. Hiscox JD, Tsraelstam GF (1979) A method for the extraction of chlorophyll from leaf tissue without maceration. Can J Bot 57:1332-1334

14. Arnon DT (1949) Copper enzyme in isolated chloroplasts polyphenoloxidase in Beta vulgaris. Plant Physiol 24:1-15

15. Radoglou K, Cabral R, Repo T, Hasanagas N, Sutinen ML, Waisel $Y$ (2007) Appraisal of root leakage as a method for estimation of root viability. Plant Biosyst 141(3):443-459

16. McKay HM (1992) Electrolyte leakage from fine roots of conifer seedlings: a rapid index of plant vitality following cold storage. Can J Forest Res 22:1371-1377

17. McKay HM (1998) Root electrolyte leakage and root growth potential as indicators of spruce and larch establishment. Silva Fenn 32:241-252

18. Heath RL, Packer L (1968) Photoperoxidation in isolated chloroplasts. Arch Biochem Biophys 125:189-198

19. Sergiev I, Alexieva V, Karanov E (1997) Effect of spermine, atrazine and combination between them on some endogenous protective systems and stress markers in plants. Compt Rend Acad Bulg Sci 51:121-124

20. Sharif I, Aleem S, Farooq J, Rizwan M, Younas A, Sarwar G, Chohan SM (2019) Salinity stress in cotton: effects, mechanism of tolerance and its management strategies. Physiol Mol Biol Plants 25(4):807-820

21. Wang J, Wang D, Fan W, Song G, Wang S, Ye W (2011) The characters of salt tolerance at different growth stages in cotton. Shengtai Xuebao Acta Ecol Sin 31:3720-3727

22. Guo-Wei Z, Hai-Ling L, Lei Z, Bing-Lin C, Zhi-Guo Z (2011) Salt tolerance evaluation of cotton (Gossypium hirsutum) at its germinating and seedling stages and selection of related indices. Yingyong Shengtai Xuebao 22:2045-2053

23. Singh J, Divakar Sastry EV, Singh V (2012) Effect of salinity on tomato (Lycopersicon esculentum Mill.) during seed germination stage. Physiol Mol Biol Plants 18(1):45-50.

24. Nedzarek A, Rakusa-Suszczewski S (2004) Decomposition of macro algae and the release of nutrients in Admiralty Bay, King George Island. Antarctica Polar Biosci 17:16-35

25. Fan D, Hodges DM, Zhang J, Kirby CW, Ji X, Locke SJ, Critchley AT, Prithiviraj B (2011) Commercial extract of the brown seaweed Ascophyllum nodosum enhances phenolic antioxidant content of spinach (Spinacia oleracea I.) which protects Caenorhabditis elegans against oxidative and thermal stress. Food Chem 124:195-202

26. Zhu GY, Kinet JM, Lutts S (2004) Characterization of rice (Oryza sativa L.) F3 populations selected for salt resistance: Relationship between yield-related parameters and physiological properties. Aust J Exp Agric 44:333-342

27. Amira H, Ghoname A, Nafeh A (2014) Alleviation of salt stress adverse effect and enhancing phenolic anti-oxidant content of eggplant by seaweed extract. Gesunde Pflanzen 67:21-31

28. Sivasankari S, Venkatesalu V, Anantharaj M, Chandrasekaran $M$ (2006) Effect of seaweed extracts on the growth and biochemical constituents of Vigna sinensis. Bioresource Technol 97:1745-1751

29. Kumar G, Sahoo D (2011) Effect of seaweed liquid extract on growth and yield of Triticum aestivum var. Pusa Gold J Appl Phycol 23:251-255

30. Jannin L (2012) Caractérisation des modifications physiologiques et métaboliques induites chez Brassica napus L. par l'apport d'extraits algaux ou d'acides humiques. Thèse de doctorat en physiologie, biologie des organismes, populations, interactions. Université de Caen Basse-Normandie. Ecole Doctorale Normande Biologie Intégrative, Santé and Environnement. Caen, France. 136p

31. Shaheen S, Naseer S, Ashraf M, Akram NA (2013) Salt stress affects water relations, photosynthesis, and oxidative defense mechanisms in Solanum melongena L. J Plant Interact 8:85-96

32. Shannon MC, Grieve CM (1999) Tolerance of vegetable crops to salinity. Sci Hortic 78(5):38

33. Ashraf M, Mc Neilly T (1988) Variability in salt tolerance of nine spring wheat cultivars. J Agron Crop Sci 160:14-21

34. Zhao H, Dai TB, Jing Q, Jiang D, Cao WX (2007) Leaf senescence and grain filling affected by post-anthesis high temperatures in two different wheat cultivars. Plant Growth Regul 51:149-158

35. Zhang L, Ma H, Chen T, Pen J, Yu S, Zhao X (2014) Morphological and physiological responses of cotton (Gossypium hirsutum L.) plants to salinity. PLoS ONE 9:e112807.

36. Bozorgi H (2012) Effects of foliar spraying with marine plant Ascophyllum nodosum extract and nano iron chelate fertilizer on fruit yield and several attributes of eggplant (solanum melongena). ARPNJ Agricul Biol Sci 7:357-362

37. Ramarajan S, Beschi A, Saravana G (2013) Effect of seaweed extracts mediated changes in leaf area and pigment 
concentration in soybean under salt stress condition. Research and reviews J Life Sci 3:17-21

38. Del Rio LA, Sandalio LM, Altomare DA, Zilinskas BA (2003) Mitochondrial and peroxisomal manganese superoxide dismutase: differential expression during leaf senescence.". J Exp Bot 54(384):923-933

39. Gill SS, Tuteja N (2010) Reactive oxygen species and antioxidant machinery in abiotic stress tolerance in crop plants. Plant Physiol Biochem 48:909-930

40. Jha Y, Subramanian RB (2013) Paddy plants inoculated with PGPR show better growth physiology and nutrient content under saline conditions. Chil J Agric Res 73:213-219

41. Mezghani S, Bourguiba I, Hfaiedh I, Amri M (2013) Antioxidant potential of Ulva rigida extracts: protection of HeLa cells against $\mathrm{H}_{2} \mathrm{O}_{2}$ cytotoxicity. Biol Bull 225:1-7

42. Sadasivam VS, Packiaraj G, Subiramani S, Govindarajan S, Ganesan KP, Manju VK, Narayanasamy J (2017) Evaluation of seagrass liquid extract on salt stress alleviation in tomato plants. Asian J Plant Sci Res 16(4):172-183

43. Yildiza GCs, Vatana O, Derea S (2012) Determination of the AntiOxidative Capacity and Bioactive Compounds in Green Seaweed Ulva rigida C. Agardh Int J Food Properties 15:1182-1189

44. Verma S, Dubey RS (2003) Lead toxicity induces lipid peroxidation and alters the activities ofantioxidant enzymes in growing rice plants. Plant Sci 164:645-655

45. Marschner H (1995) Part I-Nutritional physiology. In: Marschner $\mathrm{H}$ (ed) Mineral nutrition of higher plants, 2nd edn, pp 18-30, 313-363. Academic Press, London.
46. Blokhina O, Virolainen E, Fagerstedt KV (2003) Antioxidants, oxidative damage and oxygen deprivation stress; a review. Annals Bot 91:179-194

47. Liang Y, Chen QIN, Liu Q, Zhang W, Ding R (2003) Exogenous silicon (Si) increases antioxidant enzyme activity and reduces lipid peroxidation in roots of salt-stressed barley (Hordeum vulgare L.). J Plant Physiol 160(10):1157-1164.

48. Bensidhoum L, Ait Bessai S, Nabti EH (2019) Restoration of plant growth under saline soil by halotolerant plant growth promoting Rhizobacteria (PGPR). In: Kumar Andal M (ed) Saline soil-based agriculture by halotolerant microorganisms. Springer Nature Singapore Pte Ltd., Singapore. https://doi. org/10.1007/978-981-13-8335-9_2.

49. Nabti E, Sahnoune M, Adjrad S, Dommelen AV, Ghoul M, Schmid M, Hartman A (2007) A halophilic and osmotolerant Azospirillum brasilense Strain from Algerian soil restores wheat growth under saline conditions. Eng Life Sci 7(4):354-360

50. Arif $F(2016)$ Effet du stress salin et d'osmoprotecteurs naturels sur la germination de blé dur (Triticum durum) inoculé par Pseudomonas fluorescens. Thèse de Doctorat, Université Ferhat Abbas, Sétif 1. Faculté des Sciences de la Nature et de la Vie, Sétif, 156p.

Publisher's Note Springer Nature remains neutral with regard to jurisdictional claims in published maps and institutional affiliations. 